\title{
MISES AND ROTHBARD ON WAR FINANCE
}

\author{
GABRIEL CALZADA ÁLVAREZ*
}

\section{INTRODUCTION}

Inside the «economics of war» field of study, very few economists have tried to build a systematic theory of the consequences of the different methods of financing wars. Even fewer economists have ever attempted to elaborate a theory that meets both efficiency and ethical criteria. The first studies in this field can be traced back to the late scholastics. Francisco Suarez (15481617) and Francisco de Vitoria (1486-1546) are well known as founders of international law studies. The latter, using his characteristic juridical approach to ethical problems, concludes that the prince can use no neutral person or private property in order to wage a war ${ }^{1}$.

But it was Juan de Mariana (1536-1623) who first tried to unite the ethical and the economic dimension of war finance. Mariana started by analyzing the question of the resources the prince is allowed to use for waging a war. His answer could be described as a libertarian answer; the king is not the owner of the properties

* Profesor Asociado de Economía Aplicada, Universidad Rey Juan Carlos. The author wants to thank the Ludwig von Mises Institute for generous financial support.

1 See Francisco Suarez (1612), De Legibus ac de Deo Legislatore, Coimbra, and Francisco de Vitoria (1991), Political Writings. Cambridge: Cambridge University Press.

Procesos de Mercado: Revista Europea de Economía Política Vol. II, n. ${ }^{\circ} 1$, Primavera 2005, pp. 147 a 170 
of his subjects, and thus, he cannot dispose of them at his whim but only after having gained the acceptance of the owner. Then he turned to the different financial tools, and he described the economic consequences of their use. After dealing with the effects of taxation, inflation and the king's credit, he recommended that both the king and the citizens be aware of the ethical and practical point of views ${ }^{2}$.

After Mariana, very few thinkers have worked on war finance combining both approaches. In this last century the Austrian School of Economics has contributed to the development of the war finance theory by the hand of Ludwig von Mises and Murray N. Rothbard. The first, concentrated his analysis on the possible use of the means to wage a war, and their consequences. On the contrary Rothbard's approach is known for its focus on the ethical approach to war finance.

I hope that a careful and comparative analysis of both authors can bring new light into the theory of war finance. In order to do so, I will proceed to separate first Mises', and then Rothbard's, ideas on war finance in the following four categories: ConscriptionConfiscation, Taxation, Inflation and War Bonds. Before starting with the analysis of these methods in the works of these two authors, I will shortly explain what the conceptual reasons for this typology of war finance mean.

Through conscription and confiscation the state seizes the means of production. These are the most socialistic tools in the hands of government, and hence the most difficult to reverse. By means of taxation, the government takes over money. In this case the means of production remain in private hands, while they are allocated in response to the governmental needs through the demand exercised by the appropriated money. The inflationary finance of war consists in debasing the currency, transferring purchasing power to the state indiscriminately and perverting

\footnotetext{
${ }^{2}$ See Juan de Mariana (1609), Tratado y Discurso sobre la Moneda de Vellón. Aachen.
} 
the price system. Finally, borrowing the money to buy the war material is what I have called the finance through war bonds.

\section{MISES' WAR FINANCE THEORY}

Mises theory of war finance was developed and published over a long span stretching more than fifty years. What I will present in this paper is a body of common denominators through his different writings.

He thought that war or, at least, total war (as opposed to the "soldiers' war») is incompatible with a market economy and thus, the big question of war finance is how can a market economy mobilize its resources with the maximum efficiency, in order to win the war as soon as possible?

In order to give an answer to this vital question, Mises begins a comparative analysis of the different ways a war can be financed and their respective consequences by claiming «there were three ways available to cover the costs that the State Treasury incurred in the war» ${ }^{3}$. Nevertheless, he always wrote about four ways a war could be financed, namely, conscription and confiscation, taxes, inflation, and bonds.

3 Ludwig von Mises (1983), Nation, State, and Economy, p. 165. In Über Kriegskostendeckung und Kriegsanleihen [Mises (1918)], Mises started writing about the different existing ways to finance a war by declaring that "[s]ieht man von der vom unterliegenden Gegner zu zahlenden Kriegsentschádigung ab, so stehen dem Staatsschatze drei Wege offen, um sich die Mittel zur Bezahlung der Kriegskosten zu erwägen», committing a contradiction with his own theory since taking the resources from the enemy once this is defeated constitute a way to cover the previous finance made by other productive individuals. 


\section{CONSCRIPTION-CONFISCATION}

Regarding the question of conscription, Ludwig von Mises changed his mind during his life. Specifically, it seems that he changed from opposing conscription to a radical utilitarian defense of it during the 50's or early 60's. In his early writings and until the publication of the Second Edition of Human Action, published in 1963, Mises opposed conscription. The blood tax, as Mises called conscription, is a socialistic means to wage a war that «however high or however low the compensation of the warrior may be, it is never to be regarded as full compensation for the compulsorily recruited man. The sacrifice that is demanded of the soldier serving by compulsion can be compensated only with intangible values, never with material ones» 4 . For Mises the introduction of compulsory military service establishes the very beginning of «total war» and the end of «the soldiers" war», which was the civilizatory achievement of the market economy in an evolution "which was to bring the pacification of the world $»^{5}$; the complete elimination of war.

Thus, Mises explained in the following words how war socialism replaced the market economy through the compulsory military service:

Compulsory military service proposes putting everyone in the army who is able-bodied; only the ailing, the physically unfit, the old, the women, and the children are exempted. But when it is realized that a part of the able-bodied must be used on the industrial front for work which may be performed by the old and the young, the less fit and the women, then there is no reason to differentiate in compulsory military service thus leads to compulsory labor service of all citizens who are able to work, male and female. The supreme commander exercises power over the entire nation, he replaces the work of the able-bodied

\footnotetext{
4 Mises (1983), pp. 165-166.

5 Mises (1998a), Interventionism, p. 68.
} 
by the work of less fit draftees, and places as many able-bodied at the front as he can spare at home without endangering the supplies of the army. The supreme commander then decides what is to be produced and how. He also decides how the products are to be used. Mobilization has become total; the nation and the state have been transformed into an army; war socialism has replaced the market economy ${ }^{6}$.

It is hard to believe that the same author of this solid attack on conscription could defend it, 23 years later, in the name of praxeology. He claimed that the person who opposes conscription is an instigator or an accomplice of «those aiming at the enslavement of all» ${ }^{7}$. He even went so far as to state that «if the government of a free country forces every citizen to cooperate fully in its designs to repel the aggressors and every able-bodied man to join the armed forces, it does not impose upon the individual a duty that would step beyond the task the praxeological law dictates» ${ }^{8}$.

On the other hand, Mises never advocated confiscation as a way to finance war. In his opinion the most consistent defenders of socialism and militarism have good reasons for advocating it. The confiscation of the material goods needed for waging a war represented for him the triumph of socialism in its simplest form, and as every person that is familiar with the writings of Ludwig von Mises knows, socialism is nothing but an impossible system whose final stage is the destruction of the civilization that the free market made possible.

Moreover, confiscation cannot even attain its end, namely the supply of the goods that are needed to wage the war, if further production of this good is needed to fight the enemy. It is simply not possible to renounce the incentives that facilitate the development of the productive forces that are going to produce

\footnotetext{
6 Mises (1998a), p. 70.

7 Mises (1963), Human Action (2nd edition), p. 282.

8 Ibid.
} 
the present goods without which continuing a war would be a suicidal act. This is so because a war needs a transformation of the structure of production in accordance with the necessities of war. And in particular, a transformation capable of yielding the highest amount of war means. But without the incentive of benefit, and the punishment of loss, this difficult task turns into an impossible mission. The confiscation of the already produced goods would destroy the incentives of entrepreneurs as efficiently as the confiscation of the factors of production would eliminate prices and hence, the possibility of the necessary economic calculation to direct the scarce means toward the final goal of winning the war'.

Thus, except for his later works, Mises was not a big enthusiast of conscription and confiscation. Rather, he considered these two methods of financing war as misleading and self-defeating.

\section{TAXATION}

A second way for the State to finance war is to raise taxes or create new ones. Unlike a small war, a big war cannot be financed by taxes without putting aside consideration «for justice and uniformity in the distribution of tax burdens» and take from wherever it is easier to take at the moment ${ }^{10}$. Therefore, Mises

${ }^{9}$ In Über Kriegskostendeckung und Kriegsanleihen, p. 6, Mises wrote: «Man wollte und konnte auf den Ansporn zur höchsten Steigerung der wirtschaftlichen Kräfte, der im Eigenintereresse des einzelnen gelegen ist, nicht verzichten. Hätte die Kriegführung nur solcher Güter bedurft, die schon bei Beginn des Krieges in den Einzelwirtschaften in ausreichender Menge vorrätig waren, dann hätte man zu diesem Mittel greifen können. Mann hätte diese Güter beschlagnahmt und für den Krieg, verwendet. Doch jene Güter, deren man bedurfte, konnten bei Beginn des Krieges entweder gar nicht oder nur in unzureichender Menge vorhanden sein. Es handelte sich darum, die ganze produktion auf den Bedarf des Krieges umzustellen. [...] Die produktion aller kriegsartikel musste bis zur äussersten Grenze der Leistungsfähigkeit gesteigert werden und das konnte nur erzielt werden, indem man den Unternehmern freie Hand gab und ihr materielles Interesse anspornte».

10 See Mises (1983), p. 167 and Mises (1918), p. 7. 
thought that if a war were to be financed with taxes, the owners of «movable capital» like pension funds or savings-bank deposits would be burdened with the cost of war while the owners of «non-movable» capital like land or buildings would have to be left more or less free.

However, even in the case where the tax would be a poll-tax, a huge redistribution would take place immediately. In this case the «landowners and owners of industrial enterprises would then have been compelled to incur debt or even to sell part of their possessions». In either case the capitalists who dispose of cash would become better off at the expense of the owners of «non-movable» capital. Therefore, Mises opposed every kind of «tax on property» as a way to finance a war. «The more socialist thinking gained strength in the course of the war», he wrote, «the more people were bent on covering the war costs by special taxes on property» ${ }^{11}$.

For Mises, the one-time capital levy is another socialist idea which overwhelming popularity can only be understood in relation with the population's aversion to private property ${ }^{12}$. Apart from the fact that for an entrepreneur it can never be the same to be compelled to pay X one-time than to pay X/12 twelve times, «by the one time capital levy the state would transfer capital out of the hands of entrepreneurs into the hands of capitalists and lenders. [...] The consequence of the capital levy will therefore be a greater indebtedness of the enterprising strata of the population to the non-enterprising capitalist, who, as a result of the reduction of the war debt, will have exchanged part of their claims on the state for claims on private parties» ${ }^{13}$.

Nor does the war-profit taxation represent a realistic proposal in order to finance a war. Actually, such a tax would be more a

\footnotetext{
${ }^{11}$ Mises (1983), p. 169

12 Ibid., p. 170.

13 Ibid., p. 171.
} 
danger than a help. Although for Mises «[I]t may be admitted that it is not "fair" that war enhances the profits of those entrepreneurs who contribute best to the equipment of the fighting forces[,] [...] it would be foolish to deny that the profit system produces the best weapons. [...] The most important thing in war is not to avoid the emergence of high profits, but to give the best equipment to one's own country's soldiers and sailors. The worst enemies of a nation are those malicious demagogues who would give their envy precedence over the vital interests of their nation's cause» ${ }^{14}$.

However, Mises did not reject taxation as such, as a means to finance a war. In his view, not all kinds of taxes have a socialistic essence. And specifically, a tax that «subjects additional income and the growth of property obtained during the war to special progressive taxation» is, contrary to all other kind of taxes, not necessarily a socialistic one because «[i]n and of itself the principle of taxation according to ability to pay is not socialistic» ${ }^{15}$.

Thus, although Mises did not defend taxes in general as a way to finance war, both because of redistribution effects and incentives problems, he did not oppose taxes as such, and defended certain kind of taxation because of the necessity of a governmental defence-armed-force, and the high expenditures that it requires. "To levy taxes for these purposes is fully compatible with the freedom the individual enjoys in a free market economy. To assert this does not, of course, amount to a justification of the confiscatory and discriminatory taxation methods practiced today by the selfstyled progressive governments» ${ }^{16}$.

${ }_{14}$ Mises (1998b), Human Action, Scholar's Edition, Auburn: Ludwig von Mises Institute, p. 823 .

15 Mises (1983), p. 169. Mises continues saying that «[I]t cannot be denied that those who achieved a higher income in the war than in peacetime or had increased their property were ceteris paribus more able to pay than those who did not succeed in increasing their income or their property».

16 Mises (1963), p. 282. 


\section{INFLATION}

Inflation was the method that Mises studied and attacked the most. As early as 1912 Mises already showed up the evils of inflation hidden under the «emergency argument». Mises begun by stating that in order to understand the exact value of the inflationary-emergency-argument, «there is need to realize that inflation does not add anything to a nation's power of resistance, either to its material resources or to its spiritual and moral strength. Whether there is inflation or not, the material equipment required by the armed forces must be provided out of the available means by restricting consumption for non-vital purposes, by intensifying production in order to increase output, and by consuming a part of the capital previously accumulated. [...] The emergency that brings about inflation is this: the people or the majority of the people are not prepared to defray the costs incurred by their rulers' policies. They support these policies only to the extent that they believe their conduct does not burden themselves» ${ }^{17}$.

Six years later, Mises pointed out that although a war is always a bad business and implies in its best possible case the destruction of goods and the creation of misery, "astonishingly, however, things seemed to work otherwise [during the first world war]. Instead of the expected crisis came a period of good business; instead of decline, boom. People found that war was prosperity; businessmen who, before the war, were thoroughly peace-minded and were always reproached by the friends of war for the anxiety that they always showed at every flare-up of war rumors now began to reconcile themselves to the war. All at once there were no longer any unsalable products; enterprises that for years had run only at a loss yielded rich profits. Unemployment, which had assumed a menacing extent in the first

17 Mises (1981), The Theory of Money and Credit, pp. 467-468. 
days and weeks of the war, disappeared completely, and wages rose. The entire economy presented the picture of a gratifying boom. Soon writers appeared who sought to explain the causes of this boom» ${ }^{18}$.

If war could produce prosperity, earthquake and plagues should yield by the same reason great amounts of wealth. Since every intelligent person should know that it is logically impossible to create wealth by destroying goods and lives, Mises took up the task of explaining the economic reasons for this apparent wealth expansion by war means. First of all, Mises explained, that if not for the veil that inflation draws around the economic facts, people would quickly recognize that war prosperity was a reality for a very reduced group while the rest become poorer and more miserable every day that the war machinery goes ahead ${ }^{19}$.

But the question still remains: What is and how does this veil come about? In the first place, one has to understand that a war increases the demand for money, which creates a tendency for an increase in the purchasing power of the money unit. If the amount of new issued notes exceeds the increase in the warinduced demand for money, "the price of all goods and services, and with them the prices of foreign bills of exchange» goes up $^{20}$. Thus, creditors are harmed while debtors are favored and encouraged to engage in irresponsible behaviors.

But the increase in the prices of all goods is not homogeneous, i.e., it does not occur at one stroke everywhere and for all kinds of goods and services. It is a matter of common sense to recognize that, generally speaking, the new notes arrive first to the producers and suppliers of war materials, and only later will

\footnotetext{
18 Mises (1983), pp. 153-154.

19 This fundamental insight was the basis for a more recent article about war finance by Joseph T. Salerno. See Salerno (1997), «War and the Money Machine», in The Cost of War, pp. 367-387.

20 Mises (1983), p. 156.
} 
spread to an increasingly larger number of individuals and articles. The first holders of the new money increase their demand for various articles and «thus the prices and also the sales of the latter will rise, notably, however, also those of luxury articles. The situation of the producers of all these articles thereby improves; their demands for other goods will also increase; the rise of prices and sales will therefore progress even further and spread to an ever larger number of articles, and finally to all» 21 .

The fact that some people who receive first the newly issued money by selling the goods and services whose prices increased at the very beginning of the inflationary process, can still buy other products at the older, lower prices, makes this process a big redistribution mechanism. As Mises concluded, «That is the essence of the so-called war prosperity; it enriches some by what it takes from others. It is not rising wealth but a shifting of wealth and income» ${ }^{22}$.

Moreover, while many people interpret the increase of money at hand as an increase in its wealth, what really occurs is that they are euphorically consuming their capital. The disruption of the monetary calculation that inflation brings about, hides this fact beyond a veil; the veil of inflation. To sum up Mises answer, the supposed boom, is nothing but a vast consumption of capital and an immense redistribution of wealth from the whole society to the war-dealers.

${ }^{21}$ Auspitz and Lieben (1889), Untersuchungen über die Theorie des Preises. Leipzig, p. 64 f. Quoted by Mises (1983), p. 157.

22 Mises (1953), The Theory of Money and Credit (second edition), p. 222. 


\section{WAR BONDS}

I left the finance through War Bonds (State borrowing from the public) for the end because this was Mises' preferred way of war financing. In Mises' eyes, War Bonds are not endowed with the unlucky consequences of the other financing tools. By the contrary, to finance a war through the issuing of State Bonds has the virtue of a non-redistribution system that allows the free market to work as well as possible given the conditions of a war.

Speaking about the First World War, Mises wrote that the state covered the largest part of the war costs by incurring state debt and contracting state loans. He first rejected the common assumption that this meant a redistribution that favors capitalists, claiming that it makes possible to the owners of industries and landowners to afford their part of the cost without having to sell in bad conditions their capital goods to the capitalists that have cash at the moment. Then, he shows that if these owners of non-movable capital have to contract private credit in order to pay for the war-taxes, «land and home owners would have had to pay more interest on their private debts than they had to pay indirectly in interest on the State debt ${ }^{23}$.

In his defense of state loans through war bonds as the best way to finance a war, Mises also rejected the "generation argument» which professes that this way of financing a war shifts the costs of war from the present generation onto future ones. In doing this, he departs from his famous claim that «[w]ar can be waged only with present goods", and he continues by saying that «[one] can fight only with weapons that are already on

23 Mises (1983), p. 167. In Mises (1918), page 8, Ludwig von Mises put it in a very clear way: «Dass der Staat die Kosten des Krieges nicht zur Gänze durch Steuern, sondern zum grössten Teile durch Ausnahme von Staatschulden bestritten hat, deren Zinsen aus dem Erträgnisse der Steuern gezahlt werden, bedeutet also nicht, wie vielfach angenommen wird, eine Begünstigung der Kapitalisten. Im Gegenteil, wir müssen in dieser Politik gerade die Rücksichtnahme auf die Interessen des realen und gewerblichen Besitzes anerkennen». 
hand; one can take everything needed for war only from wealth already on hand. From the economic point of view, the present generation wages war, and it must also bear all material costs of war. Future generations are also affected only insofar as they are our heirs and we leave less to them than we would have been able to leave without the war's intervening. Whether the state now finances the war by debts or otherwise can change nothing about this fact. That the greatest part of the war costs was financed by state loans in no way signifies a shifting of war burdens onto the future but only a particular principle of distributing the war costs» 24 .

His conviction that war bonds and state loans are the best possible ways to finance war (as long as they were covered by future taxation) and that the state should be the monopolistic defense agency, might have brought him as far as to place the cause of monetary depreciation during war time, in the selfish individuals who do not buy the state war bonds ${ }^{25}$. Because, if

\footnotetext{
24 Mises (1983), p. 166. See also Mises (1918), p. 8.

25 I say «might have» because the article where he made this, and the following claims about the relation between war-loans and inflation, was published by the Austrian government without giving him the opportunity to read the printing proofs. For Ludwig von Mises commentaries about this article, see Mises (1978), Notes and Recollections, pp. 66-67.

The German text that I am paraphrasing reads:

Die Ursache der Geldentwertung liegt in der Vermehrung der Banknoten. Der Staat muss zur Notenvermehrung greifen, wenn er die Mittel zur Kriegführung nicht freiwillig auf dem Wege der Kriegsanleihen von der Bevölkerung zur Verfügung gestellt erhält. Wer Kriegsanleihe zeichnet, bekämpft daher die Notenvermehrung und damit auch die Geldentwertung; und indem er die Geldentwertung bekämpft, sichert er nicht nur sein Vermögen, soweit es in Kriegsanleihe und in anderen Staatspapieren angelegt ist, sondern zugleich auch jene Teile seines Vermögens, die in anderen Forderungstiteln angelegt sind, gleichviel, ob es Pfandbriefe, Obligationen, Landes- und Kommunanleihen, Eisenbahnschuldverschreibungen, Hypothekar- oder Wechselforderungen sind. Wenn er Ofizier, Beamter oder sonst ein mit fixen Bezügen Angestellter ist, so sicher er dabei auch sein Realeinkommen. Denn je mehr die Kaufkraft des Geldes sinkt, desto geringer wird das Realeinkommen der Festangestellten, desto weniger können sie mit ihrem Einkommen kaufen, desto weniger können sie verbrauchen. Diese Schichten sind daher ganz besonders an der Aufrechterhaltung des Geldwertes interesiert. Sie sind es auch in ihrer Eigenschaft als Gatten und Väter, denn dassselbe,
} 
people do not buy the bonds, the state would have to inflate the currency ${ }^{26}$. Thus, for Mises, to buy war bonds is both a matter of moral precept and an economic self-preservation ${ }^{27}$.

\section{ROTHBARD ON WAR FINANCE}

In contrast to his mentor, Murray Rothbard did not restrict himself to the question of how a market economy can mobilize its resources with the maximum efficiency. Rather, he almost ignores this question. However, he did analyze the problem of war finance in virtually every one of his numerous works. In order to succeed in attaining this goal without even trying to answer the aforementioned question, he took what it could be called «the ethical shortcut».

In fact, he applied the libertarian axiom of «non-aggression» to all possible methods of war finance and then defended and studied the ones that passed the test. Of course, by definition, only the voluntary ways of war financing could logically past this test. But what about the different consequences of the remaining ways that exist to finance a war? Rothbard also wrote a systematic typology of governmental intervention (in which we can find some examples related to war), from which we could derive further implications for this field of study.

was von ihren Gehalten gilt, gilt auch von den Versorgungsgenüssen der Witwen und Waisen, gleichviel, ob diese Pensionen und Erziehungsbeiträge vom Dienstgeber geleistet werden, oder als Versicherungssummen von einer Versicherungsanstalt.

So ist denn jeder einzelne im höchsten Masse daran interessiert, dass der Erfolg der Kriegsanleihen ein günstiger werde. Wer Kriegsanleihe zeichnet, macht nicht nur im eigentlichen Sinne ein gutes Geschäft, indem er sich für sein Vermögen eine hohe Verzinsung sichert, er fördert auch indirect seine wirtschaftlichen Interessen, indem er das weitere Sinken der Kaufkraft des Geldes, die weitere Steigerung aller Warenpreise verhindert. Es ist nicht nur patriotische Pflicht, Kriegsanleihe zu zeichnen, sondern auch Gebot der wirtschaftlichen Selbsterhaltung.

26 Mises (1918), p. 13.

27 Ibid., p. 14. 
Fortunately, our task will not have to be as risky as it seems to be, since it is not completely true that Rothbard never wrote about war finance. Around 1950 he produced a small paper on war finance that has been never published, in which he deals briefly with all different ways of war financing, that together with his extensive works on ethic, economic, and history, gives a quite precise idea on, what could be called, a Rothbardian theory of war finance 28,29 .

\section{CONSCRIPTION AND CONFISCATION}

Conscription would qualify for Rothbard as a binary intervention, i.e., a violent intervention characterized by the fact that the aggressor compels a subject to realize an «exchange» with himself, or to give him a gift ${ }^{30}$. It is needless to say that Rothbard always attacked conscription, and he did it from an ethical point of view- a point of view that, if consistent, can only conclude that conscription is a kind of slavery, a very perverted one indeed ${ }^{31}$. It entails a slavery-for-your-own-defense based system where the master is a group of people that call themselves the government and proclaim to be the monopoly of defense services, but that do not really defend their slaves. Instead, they enter into war, and then they forced their slaves to sacrifice their freedom, their money, and their lives in order to defend, not themselves, but their masters. For Rothbard, «[o]f all the ways in which war aggrandizes the State, this is perhaps the most flagrant and most despotic. But the most striking fact about conscription is

\footnotetext{
${ }^{28}$ I would like to thank Joseph Stromberg for putting me in contact with this paper and for all his wise orientation during the research of this work.

29 Rothbard's paper on war finance is titled «The Economics of War».

${ }^{30}$ For a typology of intervention by Murray Rothbard see Rothbard (2004), Man, Economy, and State with Power and Market, Scholar's Edition, pp. 887-1025, and 11571295.

31 See Rothbard (1982), The Ethics of Liberty, especially, pp. 83 and 136-137.
} 
the absurdity of the arguments put forward on its behalf. A man must be conscripted to defend his (or someone else's?) liberty against an evil State beyond the borders. Defend his liberty? How? By being coerced into an army whose very raison d'etre is the expunging of liberty, the trampling on all the liberties of the person, the calculated and brutal dehumanization of the soldier and his transformation into an efficient engine of murder at the whim of his "commanding officer"? Can any conceivable foreign State do anything worse to him than what "his" army is now doing for his alleged benefit? Who is there, O Lord, to defend him against his "defenders"?»32.

Conscription reduces the general productivity of the economy by pulling out at least some productive workers from their productive jobs and, at the same time, it serves as a means for imposing restrictionist wage rates by removing part of the labor force ${ }^{33}$.

Rothbard was not more acquiescent in the case of confiscation. Again, from the ethical perspective, he saw confiscation as a pure and rude robbery.

\section{TAXATION}

Taxation is also a binary intervention under Rothbard's typology. The levying of taxes is the force on which all states and all governments rest, whose health is nothing but war ${ }^{34}$.

Thus, societies with a state have to be divided between taxpayers and tax-consumers; the productive and the looters. And even a war cannot change this fact, although it can aggravate

32 Rothbard (1963), «War, Peace and the State», The Standard, II, 5, April 1963, p. 16.

33 Rothbard (1970), p. 56.

34 Today's popular idea that «war is the health of the state», was first enunciated and developed by Randolph Bourne, in «Unfinished Fragment on the State», in his Untimely Papers (N.Y.: B.W. Heubsch, 1919). 
it. However, not all taxes have the same effects on the economy, and the special characteristics of war can make some of them more destructive then others.

Certainly, Rothbard was on this point more systematic than Mises. He rejected the income tax as a way to finance war and he demonstrated that reductions of this tax would be, in fact, the best war financing policy because «savings should be encouraged to promote the war effort, and, to this end, individual income taxes should be reduced, rather than increased, especially and drastically in the upper income brackets» 35 . The reason for this statement is twofold. On one hand, a tax on incomes reduces savings and investments because it diminishes the return from investing below what the free-market time preference would otherwise establish. On the other hand, Rothbard maintained that this tax provokes a decrease of the taxpayer's real income and, "given a man's time-preference schedule, the lower the level of his real monetary assets, the higher his time-preference rate will be, and therefore the higher the proportion of his consumption to investment» ${ }^{36}$.

Moreover, he wrote against the progressive structure of any tax, and especially income tax, because of the way it discriminates against higher income brackets, which, by the way, usually are the ones that save more ${ }^{37}$.

He also knocked down the argument that says that an excessprofits tax is a convenient tax during war times. Nobody making such arguments could have ever seen a corporation, which receives, and uses income. Thus, Rothbard's argument runs, it is a discriminatory double taxation that penalizes efficient corporations and favors inefficient ones. It would be a task for unusually persuasive politicians to convince anyone

35 Rothbard (1950), p. 5.

36 See Rothbard (1993), Man, Economy and State, p. 798. For an explanation of the time preference schedule, see chapter 6.

37 Rothbard (1950), p. 6. 
that such discrimination could have any good effect on waging a war.

How is an entrepreneur supposed to direct the productive resources in the best possible ways and combinations to produce the best war materials if profit-and-loss signals cannot possibly serve as the means for economic calculation? «It is curious that in wartime, precisely when it would seem most urgent to preserve an efficient productive system, the cry invariably goes up for "taking the profits out of war". This zeal never seems to apply so harshly to the clearly war-borne "profits" of steel workers in higher wages-only to the profits of entrepreneurs. There is certainly no better way of crippling a war effort ${ }^{38}$.

After asking himself how best to transfer the requisite purchasing power needed to wage a war from the citizens to the government, using the least self-defeating tax and the one that can contribute more to the war effort, Rothbard concludes that such a tax can only be a general sales tax. It has the virtue of «tapping funds from private consumption expenditures», being universal, and very difficult to evade ${ }^{39}$. «Thus, if the market has been spending heavily on clothing, and the government uses the revenue mostly for the purchase of arms, there will be a fall in the price of clothes and a rise in the price of arms, and a tendency for nonspecific factors to shift out of the production of clothing and into the production of armaments ${ }^{40}$. Another tax that would qualify for being used during a war is the specific excise tax. This tax can reduce consumer spending on particular goods that are needed for war material production. As an example, «there might be special excise taxes on durable consumer goods,

38 Rothbard (1993), p. 806, where he also concludes: «In short, the excess profit tax tends to freeze the process of production as of the peacetime base period. And the longer the war lasts, the more obsolete, the more inefficient and absurd, the base-period structure becomes».

39 Rothbard (1950), p. 4.

40 Rothbard (1993), p. 812. 
such as automobiles, radios, houses, etc. that use material particularly needed for war goods» ${ }^{41}$.

\section{INFLATION}

About this method of finance, Rothbard followed Ludwig von Mises very closely. Even so, he left us some interesting remarks on the precise way governments have been involved in the "counterfeiting business» in order to finance wars. Usually, governments printed war bonds and requested the banking system buy them. The government prints war papers and exchange them for bank deposits. Now, the government goes to the market with newly created purchasing power, and places its orders for war supplies or any other fancy kind of goods or services. Speaking about the inflationary method of finance adopted in the Second World War, Rothbard explains that «[a]s the new funds found their way into the economy, money incomes of consumers increased still further. Prices rose as money expenditures rose, competing for a scarcer supply of consumer goods. Thus, instead of consumer spending being restricted, this inflationary method of finance increased consumer incomes and encouraged their spending. Hence the feeling of easy money, and heavy pressure for spending ${ }^{42}$.

Aside from this, Rothbard also pointed out how governments historically create inflation to finance their war adventures, and the final consequences of these historical misfortunes. In What has Government Done to Our Money, he tells us about an large array of inflationary war disasters. As an example, in the United States, he says, «mass suspension of specie payment in times of bank troubles became almost a tradition. It started in

${ }^{41}$ Rothbard (1950), p. 5.

42 Ibid., p. 7. 
the War of 1812. Most of the country's banks were located in New England, a section unsympathetic to America's entry into the war. These banks refused to lend for war purposes, and so the government borrowed from new paper money to make the loans. The inflation was so great that calls for redemption flooded into the new banks, especially from the conservative nonexpanding banks of New England, where government spent most of its money on war goods. As a result, there was a mass "suspension" in 1814, lasting for over two years (well beyond the end of the war)» ${ }^{43}$.

In addition to these remarkable contributions to the Misesian insights on the inflationary method of war finance, Rothbard saw very clearly the dynamic of interventionism applied to this «arena». The inflationary pressure, he said, «led the government to adopt the whole apparatus of price controls and rationing, that bedeviled the nation during and after the war» ${ }^{44}$.

\section{WAR BONDS}

In this question, Rothbard kept some distance from Mises' point of view. First of all, Rothbard did not maintain that this finance method is not a redistributive one. On the contrary, he interpreted the purchase of war bonds (and any other kind of state bonds) as the purchase of a claim or stock of the organized crime agency ${ }^{45}$. Such bonds are not to be confused with voluntary private debts, rather, the purchase of state bonds is always «a voluntary participation in future confiscation to be committed by the government ${ }^{46}$.

\footnotetext{
43 Rothbard (1990), What Has Government Done to Our Money?, pp. 70-71.

${ }^{44}$ Rothbard (1950), p. 7.

45 See Rothbard (1993), chapter 12, and Rothbard (1992), chapters 22 and 24.

46 See (1993), p. 882.
} 
It is hard to understand why many people, and even economists think that there is something heroic to be found in the purchase of the state war bonds. Contrary to Mises, Rothbard's view on this matter is that «there is nothing very patriotic about buying a bond, with the assurance that the principal will be returned, and that you will obtain a safe interest income out of the already burdened taxpayers. Moreover, these funds would mainly come out of savings, funds which otherwise would have been invested in industry» 47 .

Furthermore, he attacked the tricky phrase that claims, "public debts do not matter» because «it is something that we owe ourselves» for its holistic roots. Finally he also rejected «right-wing» attacks on public debt repudiation for being inconsistent with the free market ideas.

\section{CONCLUSIONS}

Mises defends a war finance based on state loans and certain kind of taxation, namely, a progressive tax that subjects additional income and the growth of property obtained during the war time. These are for Mises the only two possibilities that allow one to finance a war without provoking redistribution of incomes and of the ownership of the factors of production.

And it was precisely for their redistribution effects and the way they hamper the free market and destroy liberty and civilization, that he attacked the other forms of taxation, conscription, confiscation and the inflationary finance of war. This last one, was in his opinion the most dangerous tool for financing war and the most beloved gun of militarism. «One can say without exaggeration that inflation is an indispensable intellectual means of militarism. Without it, the repercussions

47 Rothbard (1950), p. 3. 
of war on welfare would become obvious much more quickly and penetratingly; war-weariness would set in much earlier ${ }^{48}$.

Rothbard tried, at least in his early years, to study the question of war finance from a double perspective: The maximum efficiency and maximum respect for liberty in mobilizing resources for waging a war. Trying to come up with practical as well as sound ethical solutions, he defended all kinds of voluntary ways of war finance and he established a preference scale for the rest of the non-voluntary finance methods. In this scale, indirect taxation would occupy the highest position. Specifically, he saw in a general sales tax, the best possible mobilizing effects combined with the least violent attack on private property.

\section{REFERENCES}

Auspitz, R. and Lieben, R. (1889), Untersuchungen über die Theorie des Preises. Leipzig.

Bourne, R. (1919), Untimely Papers. B.W. Heubsch: New York. MARIANA, J. de (1987), Tratado y discurso de la moneda de Vellón que al presente se labra en Castilla, y de algunos desórdenes $y$ abusos. Originally written in Latin under the title De monetae mutatione and translated by the author. With an introductory study by Lucas Beltrán. Instituto de Estudios Fiscales: Madrid.

Mises, L. v. (1912), Theorie des Geldes und der Umlaufsmittel. Munich.

- (1918), «Über Kriegskostendeckung und Kriegsanleihen». Transcription of a work presented by Mises to a group of officials of the Austrian Army. Phoebus: Wien.

48 Mises (1983), p. 163. 
- (1953), The Theory of Money and Credit. Second edition. Translated by H.E. Batson. Yale University Press: Yale.

- (1981), The Theory of Money and Credit. Third edition. Translated by H.E. Batson. Liberty Fund: Indianapolis.

- (1983), Nation, State, and Economy, Contributions to the Politics and History of our Time. Translated by Leland B. Yeager from the original German version. New York University Press: New York.

- (1963), Human Action: A Treatise on Economics. ( $2^{\text {nd }}$ edition). Yale University Press: New Haven.

- (1978), Notes and Recollections. With a foreword by Margit von Mises. Translated and Postscripted by Hans F. Sennholz. Libertarian Press: South Holland, Illinois.

- (1998a), Interventionism. Translated from the German manuscript [1940] by Thomas Francis McManus and Heinrich Bund. The Foundation for Economic Education: Irvington-on-Hudson, N.Y.

- (1998b), Human Action, Scholar's Edition. Auburn, Alabama: Ludwig von Mises Institute.

Rothbard, M.N. (1950), «The Economics of War». Unpublished manuscript.

- (1982), The Ethics of Liberty. Humanities Press Inc.: Atlantic Highlands, N.J.

- (1963), «War, Peace and the State». The Standard, Vol. II, n. 5, pp. 2-5, 15-16.

- (1993), Man, Economy and State. A Treatise o Economic Principles. Auburn, Ala.: Ludwig von Mises Institute.

- (1970), Power and Market: Government and the Economy. Sheed Andrews and McMeel, Inc.: Kansas City.

- (1990), What has Government Done to Our Money? Ludwig von Mises Institute, Auburn University: Auburn, Alabama. 
- (2004), Man, Economy, and State: A Treatise on Economic Principles with Power and Market: Government and the Economy, Scholar's Edition. Ludwig von Mises Institute: Auburn, Alabama.

SALERNO, J.T. (1997), «War and the Money Machine: concealing the cost of war beneath the veil of inflation». Published in John V. Denson (editor), The Cost of War; America's pyrrhic victories. Transaction Publishers: New Jersey.

SuÁReZ, F. (1612), De Legibus ac de Deo Legislatore. Coimbra.

Vitoria, F. de (1991), Political Writings. Cambridge: Cambridge University Press. 